\title{
Dynamic Analysis of a Multistory Frame RC Building with and Without Floating Columns
}

\author{
Ahmed Ibrahim ${ }^{1, *}$, Hamed Askar ${ }^{2}$ \\ ${ }^{1}$ Civil Engineering Department, Delta University for Science and Technology, Gamasa City, Egypt \\ ${ }^{2}$ Structural Concrete, Structural Engineering Department, University of Mansoura, Mansoura, Egypt
}

Email address:

ahmdimm@hotmail.com (A. Ibrahim)

${ }^{*}$ Corresponding author

\section{To cite this article:}

Ahmed Ibrahim, Hamed Askar. Dynamic Analysis of a Multistory Frame RC Building with and without Floating Columns. American Journal of Civil Engineering. Vol. 9, No. 6, 2021, pp. 177-185. doi: 10.11648/j.ajce.20210906.11

Received: September 22, 2021; Accepted: October 26, 2021; Published: November 10, 2021

\begin{abstract}
This paper tends to evaluate the behavior of five- story RC building with and without floating columns using RC frames as lateral resisting system. This investigation had been carried-out using ETABS Ultimate V.18.1.1. The defined load cases, load combinations, the equivalent static lateral load pattern, and the response spectrum function were defined according ASCE7-16. The design criteria were set to be according to ACI 318-14. Eleven cases were proposed to investigate this behavior. One case was the building without floating columns. Nine cases were the building with different floating column schemes and the final case was the building with floating columns and another lateral resisting system (shear walls) for comparison purpose. Further comparisons of the results for all models are executed on the basis of parameters such as, story displacement, story drift, story stiffness, and response spectrum modal period. The results showed that, although the floating columns play an important role in architectural divisions or in multi-use buildings, but it affected the stiffness of the building negatively that led to increasing of the story lateral displacement and drift, also it led to increasing of modal time period. This mostly led to using a more stiffness lateral resisting system and eventually increasing the building's structural costs.
\end{abstract}

Keywords: Dynamic Analysis, Floating Columns, RC, ETABS, Response Spectrum, ASCE, ACI 318

\section{Introduction}

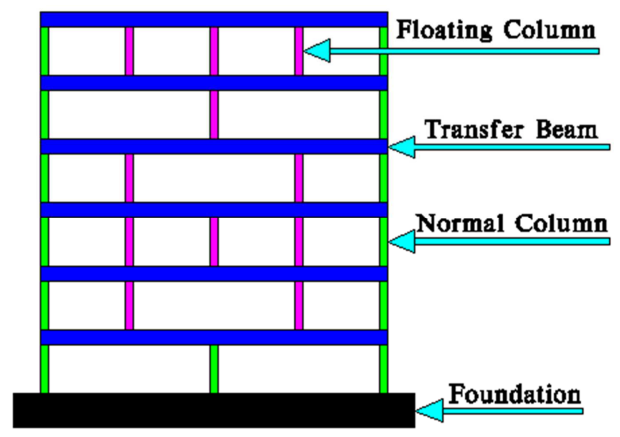

Figure 1. Example of building with floating columns.

Floating column is a vertical member that transfers load to a supporting beam. This beam transfers the load of the floating column to other columns below it. In contrast to normal column or continuous column which delivers the load to foundation directly as shown in Figure 1. Due to the architectural needs for the multi-use buildings, the existence of floating columns became a necessary. Many researches had been carried-out to investigate the behavior of the building with floating columns. For example, Thomas and George [1] investigated the performance of building with and without floating column under different soil condition and different zone conditions. Dynamic analysis was carried out for six story building with eight numbers of floating columns in between second and third floor were considered. Also, Prasannan and Mathew [2] studied the seismic response of building with floating columns and they aimed to find out the most suitable configuration for providing floating columns. In addition, Chaudhari and Talikoti [3] studied the seismic behavior of building with different positions and types of floating column. The aim of this work was to compare the response of RC frame buildings with different types of floating columns under earthquake loading using ETABS software. Further, Gupta and Kumar [4] studied the effect of floating columns in $\mathrm{RC}$ frame structure for $\mathrm{G}+14$ stories at 
different seismic zones in India and also studied the effect of position of floating columns at different locations in the considered plan. Moreover, Maitra and Serker [5] studied the performance of floating column building and compared it with normal building under seismic load. They proposed different cases of the building with varying the location of floating column and increasing the column size. Furthermore, Rangwala and Singh [6] used static analysis to evaluate the presence and absence of floating column in high rise RC frames with and without infill walls for these two different cases of RC frames. Four models were executed. This seismic analysis is executed using ETABS software as per the provisions of IS: 1893-2002 code. Patel et al. [7] carried-out analytical study based on SAP 2000 software for $\mathrm{G}+3$ buildings having floating columns in order to obtain the effects of mass variations and infill walls on behavior of normal and floating column building. The results reveal that infill walls provide seismic strengthening of the floating column building. It also helps to reduce seismic response of the building. Abdul Azeed et al., [8] carried-out analytical study for a residential multistoried building consisting of $\mathrm{G}+6$ considering different cases of removal of columns in different positions and in different floors of the building using ETABS software. Gokul and Manju [9] studied the effect of various lateral stability techniques to the building with floating columns using response spectrum analysis to find out the most appropriate configuration for providing floating columns.

The significance of this research is that it aims to carry-out a dynamic analysis of a multistory frame RC building with and without floating columns, to evaluate the effect of the number and the story location of the floating columns, and to study the behavior of the building with floating columns over cantilever beams.

\section{Description of Models}

Eight cases had been proposed to assess the behavior of a five-story frame RC building $(14.0 \times 14.0 \mathrm{~m})$ with and without floating columns. Story height was taken equal to $3.0 \mathrm{~m}$. Concrete compressive strength was assumed to be $f_{c}^{\backslash}=$ $40 \mathrm{MPa}$ and the concrete density was $25 \mathrm{kN} / \mathrm{m}^{3}$. The yield strength of reinforcement was $f_{y}=420 \mathrm{MPa}$. The own weight of members was calculated by ETABS. Walls load was added to covering materials load and assumed to be equal to $13 \mathrm{kN} / \mathrm{m}^{2}$ and Live load was assumed to be equal to $3 \mathrm{kN} / \mathrm{m}^{2}$. The proposed geometry of the supporting elements is shown in Table 1. Also, the proposed cases for this study are shown in Table 2 and in Figure 2 to Figure 13.

Table 1. Geometry of columns, beams and shear walls.

\begin{tabular}{ll}
\hline Member & Dimension, mm \\
\hline Slabs & Thickness $=150$ \\
Beams & B $(400 \times 700)$ \\
Columns & C1 $(500 \times 500)$ For $1^{\text {st }}$ floor. \\
Shear walls & C $2(400 \times 400)$ For repeated floors. \\
\hline
\end{tabular}

Table 2. Details of the Models.

\begin{tabular}{ll}
\hline Model No & Specification \\
\hline 1 & Without floating columns \\
2 & Five floating columns above the $1^{\text {st }}$ floor \\
3 & Nine floating columns above the $1^{\text {st }}$ floor \\
4 & Thirteen floating columns above the $1^{\text {st }}$ floor \\
5 & Sixteen floating column above the $1^{\text {st }}$ floor \\
6 & Sixteen floating column above the $2^{\text {nd }}$ floor \\
7 & Sixteen floating column above the $3^{\text {rd }}$ floor \\
8 & Sixteen floating column above the $4^{\text {th }}$ floor \\
9 & Twenty floating columns above cantilever beams of the $1^{\text {st }}$ floor \\
10 & Four floating columns above the $1^{\text {st }}$ floor + Four floating columns above the $2^{\text {nd }}$ floor + Four floating columns above the $3^{\text {rd }}$ \\
11 & floor + Twenty five floating columns above the $4^{\text {th }}$ floor on cantilever beams \\
\hline
\end{tabular}
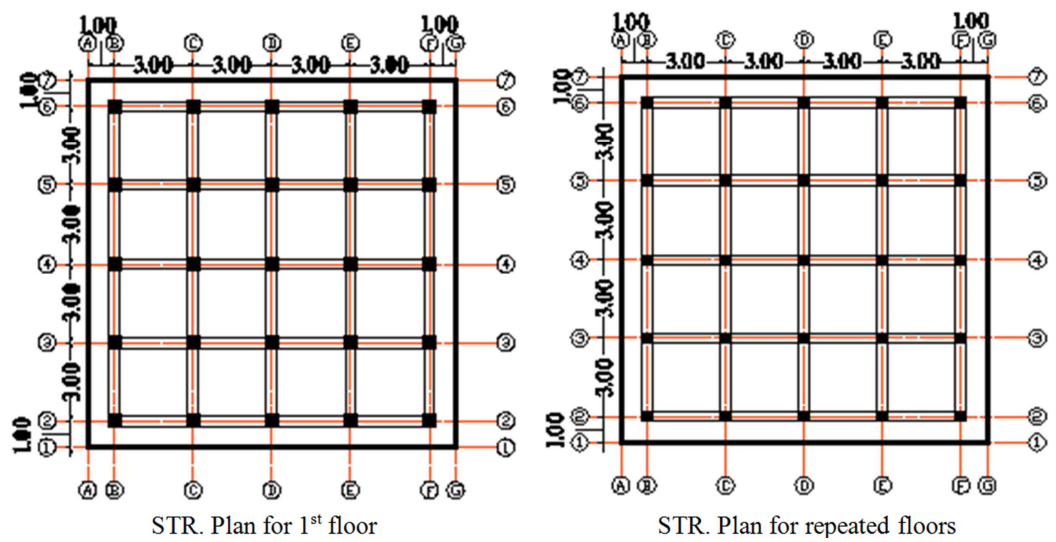

Figure 2. Layout of Model (1). 

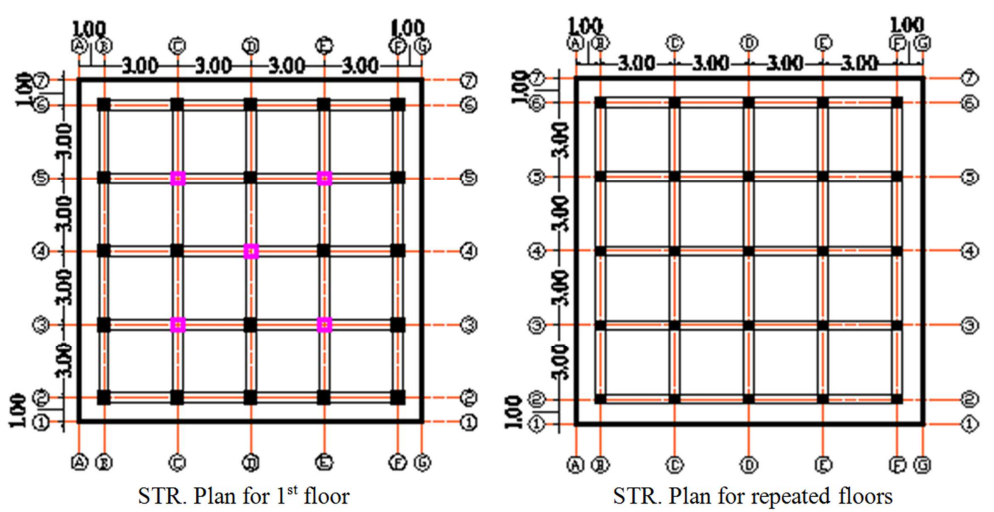

Figure 3. Layout of Model (2).
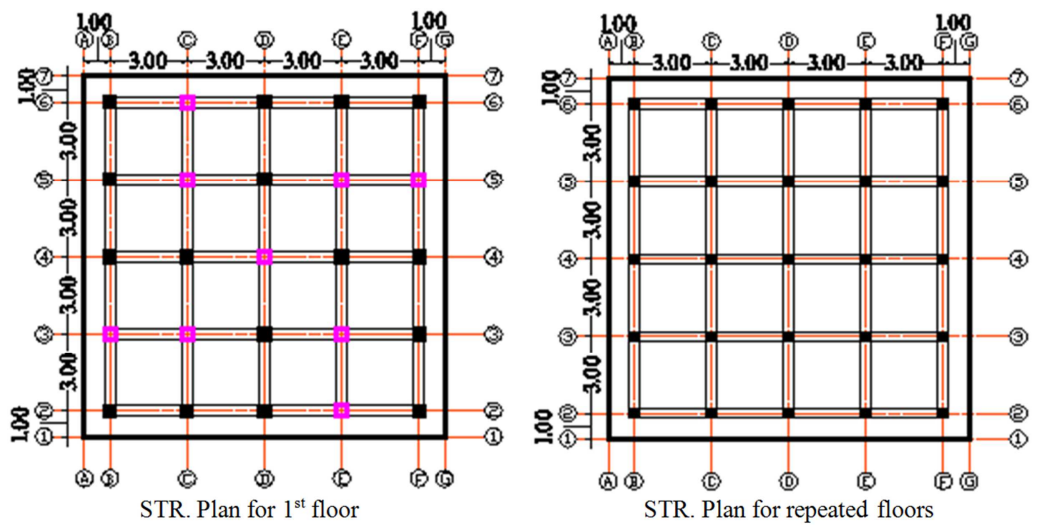

Figure 4. Layout of Model (3).
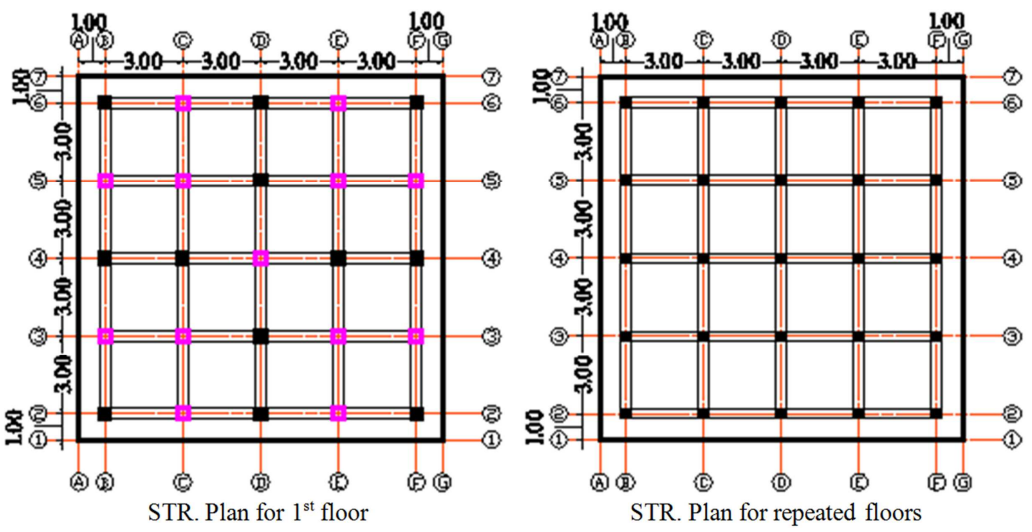

Figure 5. Layout of Model (4).
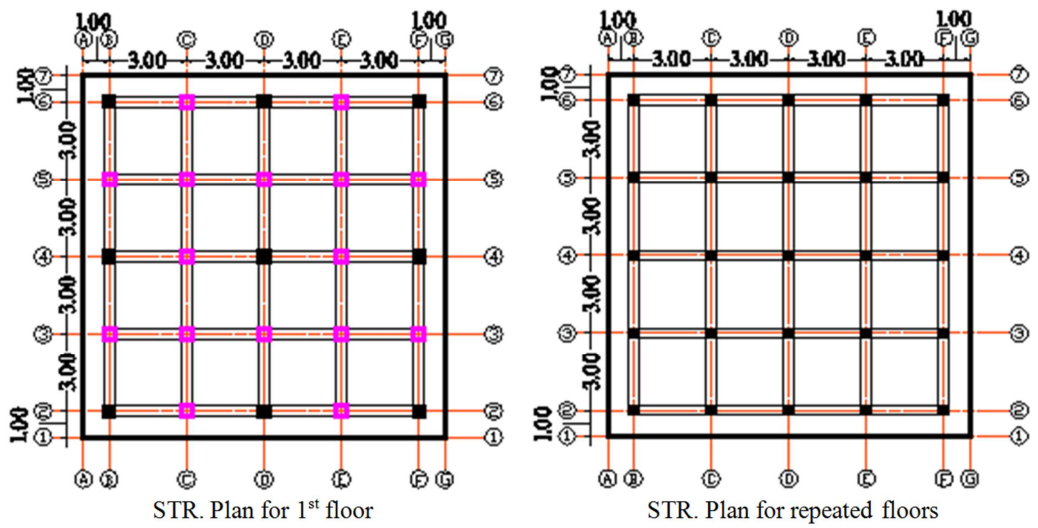

Figure 6. Layout of Model (5). 

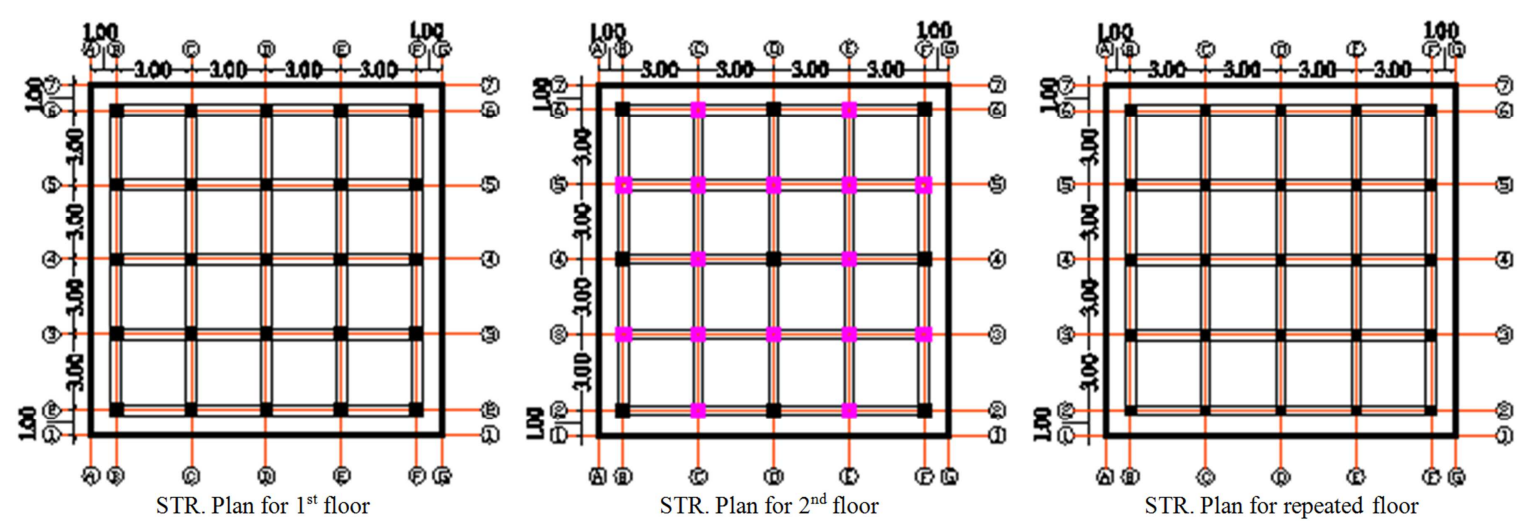

Figure 7. Layout of Model (6).
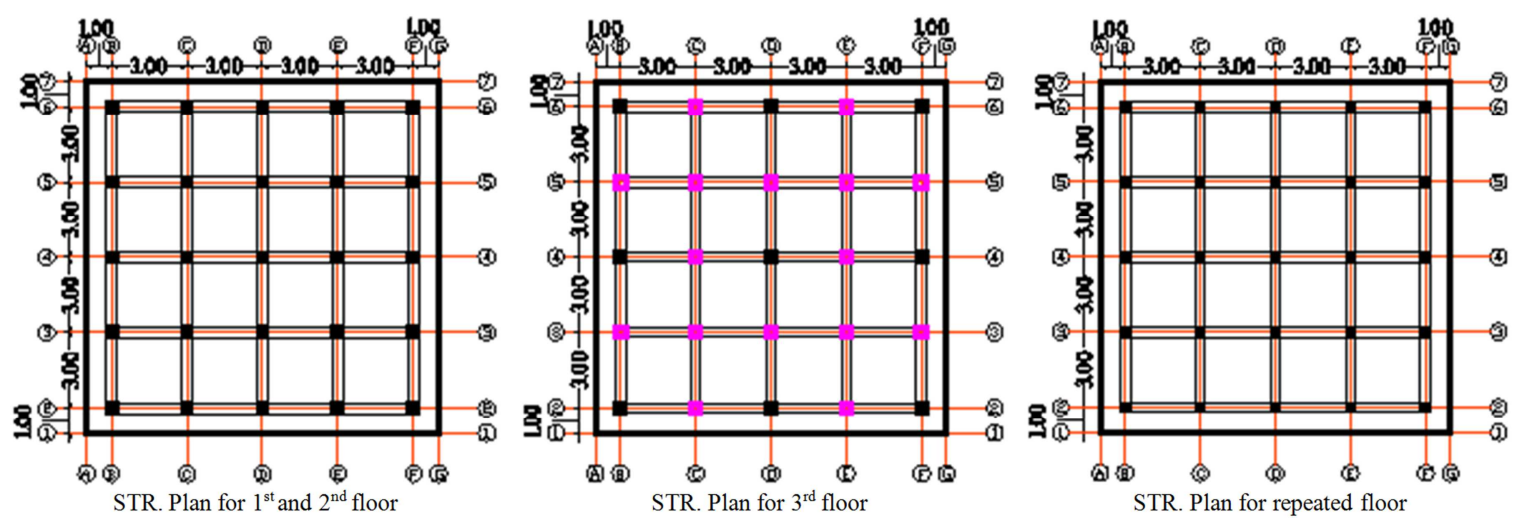

Figure 8. Layout of Model (7).
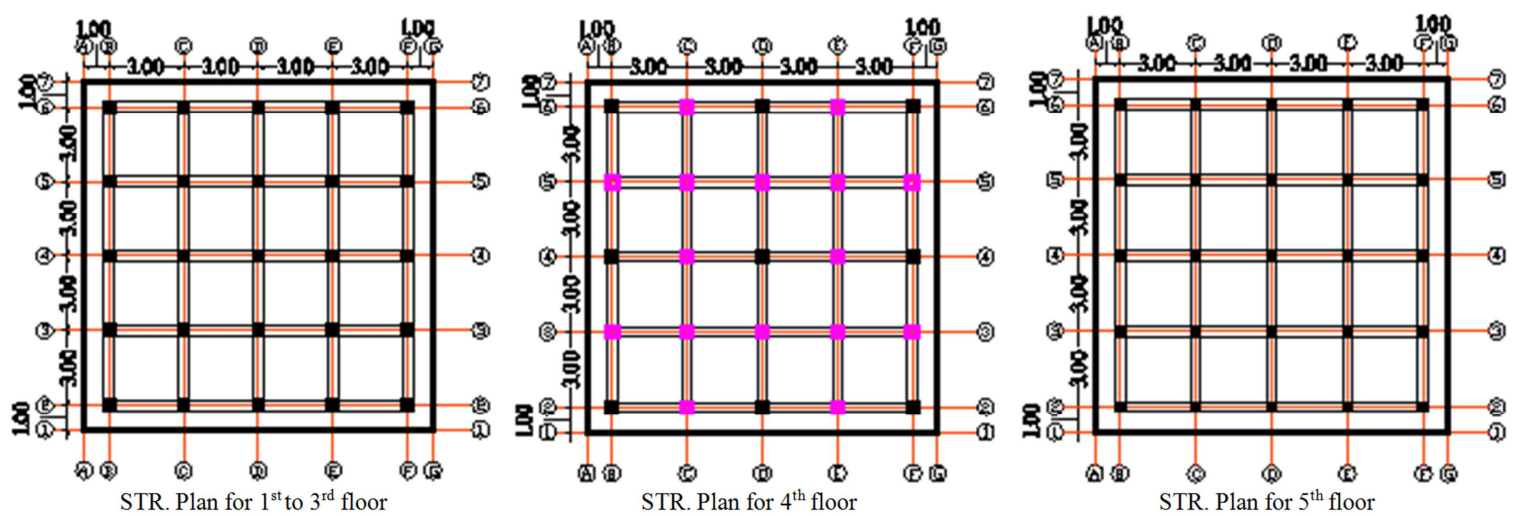

Figure 9. Layout of Model (8).
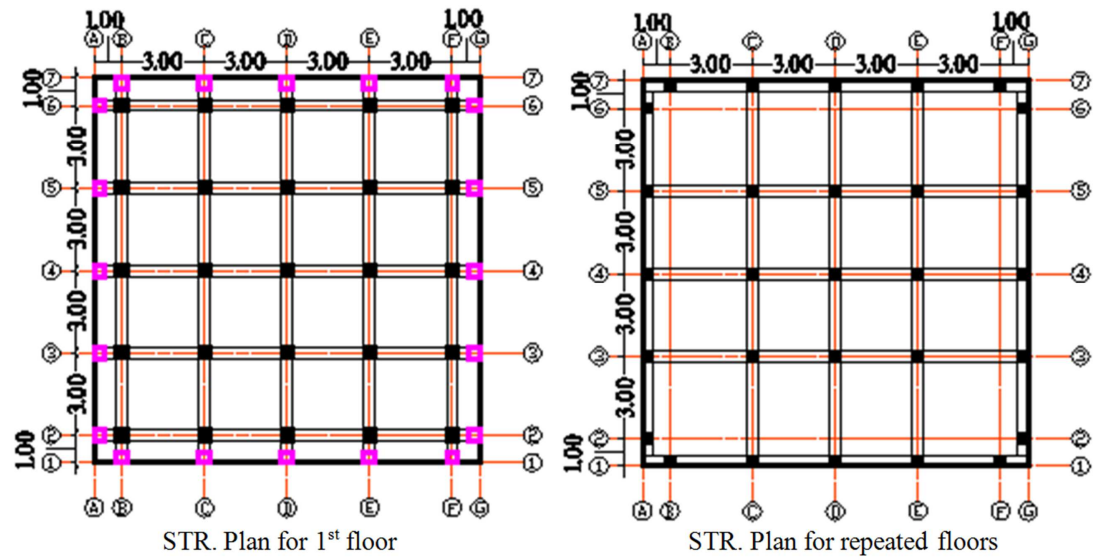

Figure 10. Layout of Model (9). 

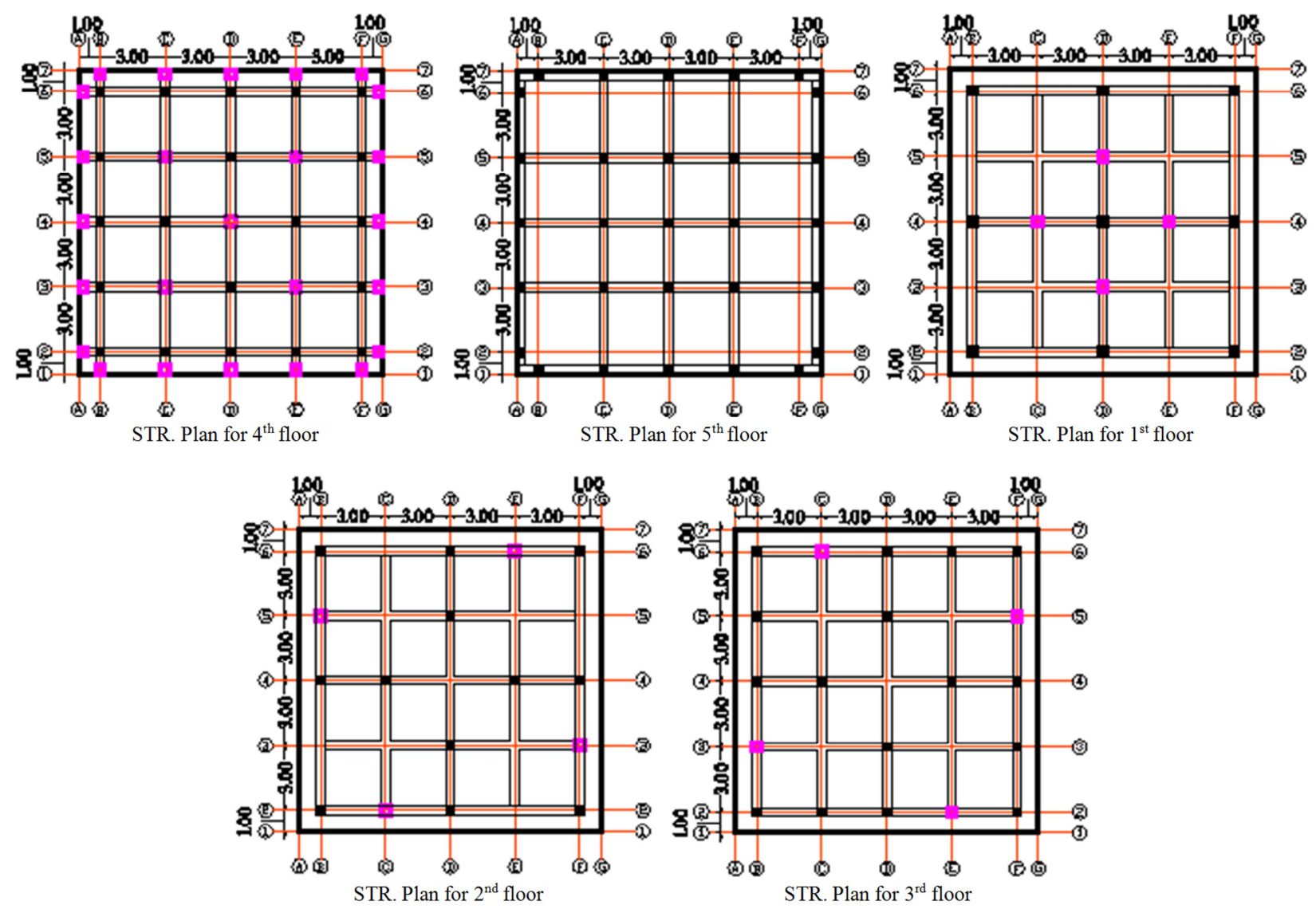

Figure 11. Layout of Model (10).
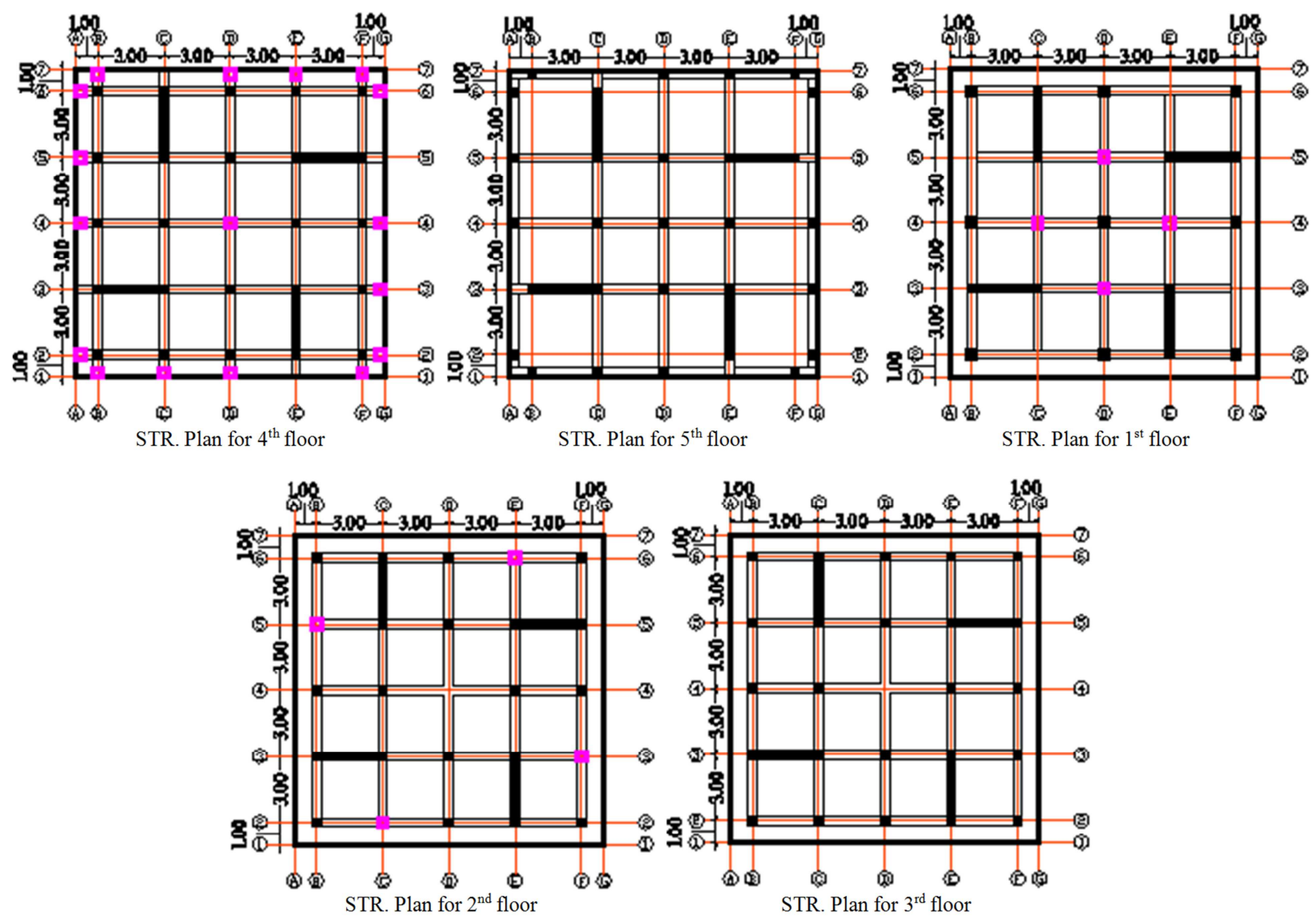

Figure 12. Layout of Model (11). 


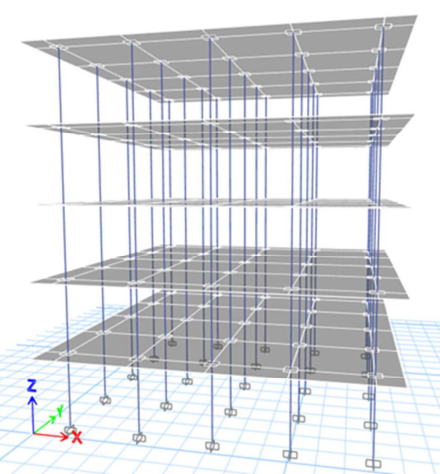

Model (1)

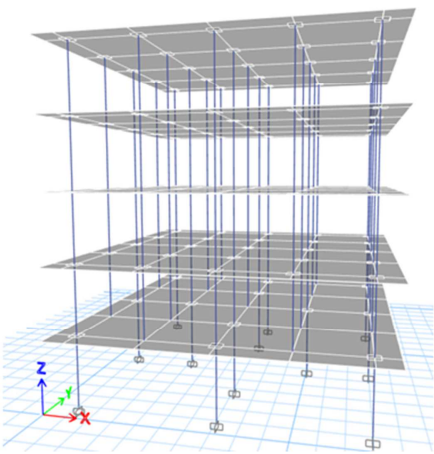

Model (4)

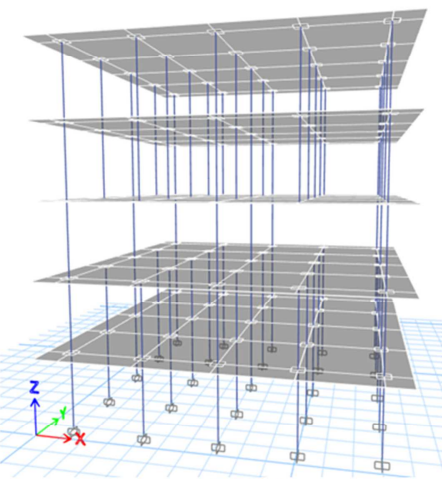

Model (7)

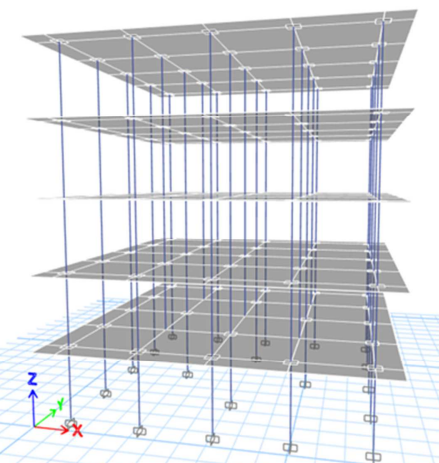

Model (2)

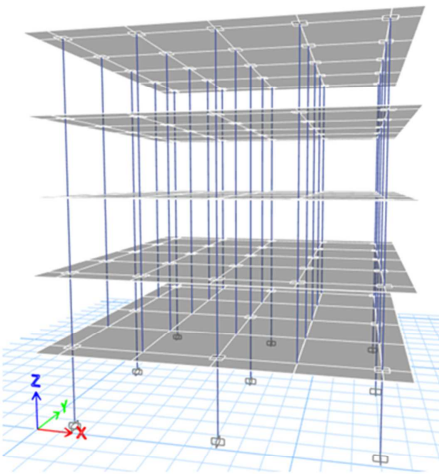

Model (5)

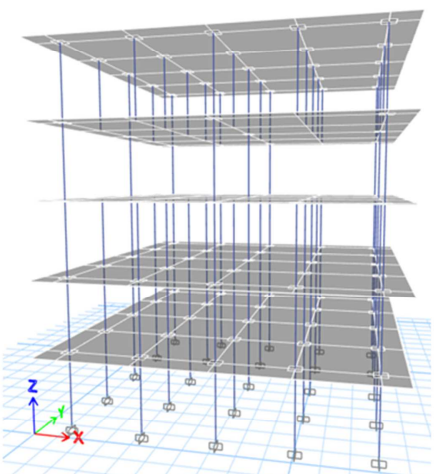

Model (8)

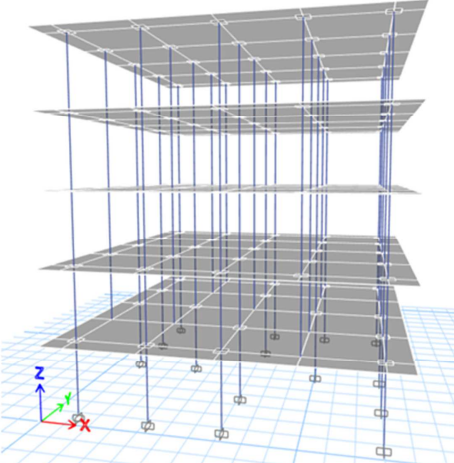

Model (3)

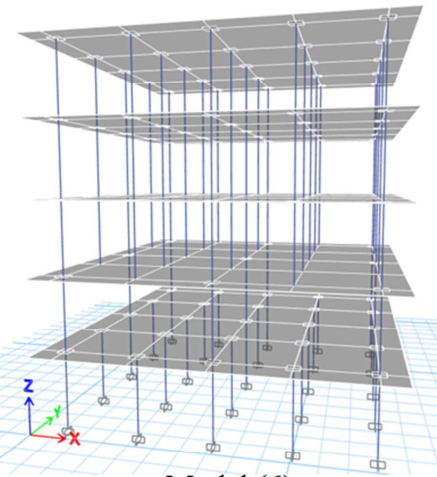

Model (6)

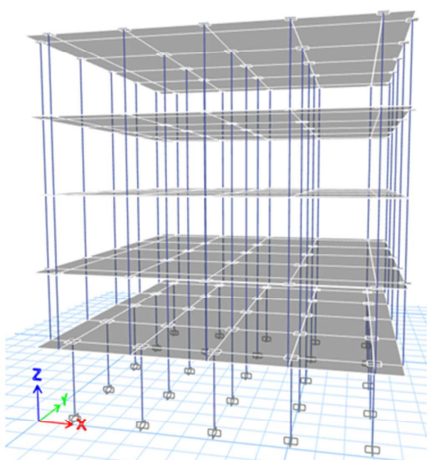

Model (9)

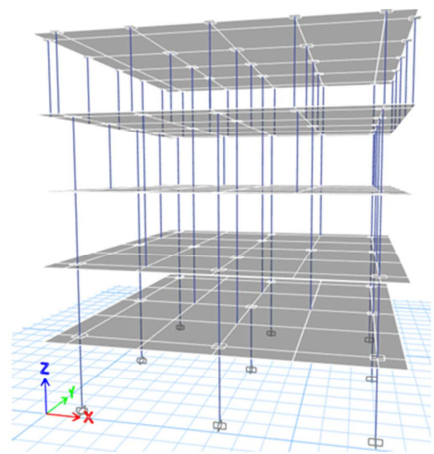

Model (10)

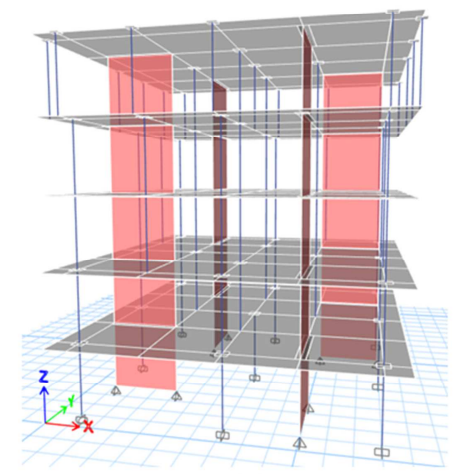

Model (11)

Figure 13. All cases modelling in ETABS.

\section{Seismic Analysis}

Modal analysis was performed and checked, so that the mass participating ratios were larger than 90\%, (ASCE7-16
[10]). To check the results of the building under the response spectrum analysis, all cases were performed under the equivalent static analysis and under the response spectrum analysis, then the base shear resulted from the response spectrum analysis was compared to the base shear resulted 
from the equivalent static method and the percentage between them was assured to be equal to $100 \%$, (ASCE7-16 [10]). Also, the concrete dimensions and the reinforcement of the supporting elements of case (1) were checked according to the ACI 318-14 [11]. The seismic data was constant for all models, as shown in Table 3.

Table 3. Seismic data for all models.

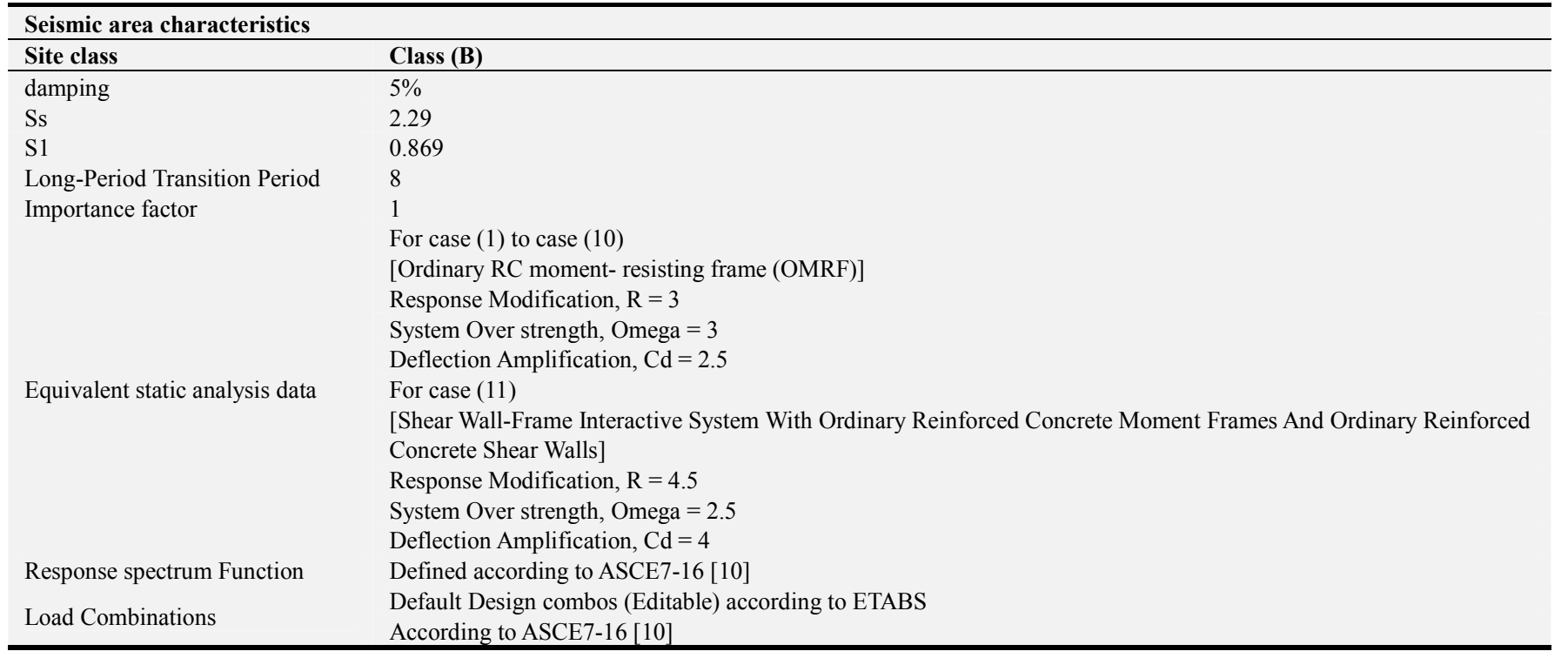

\section{Analysis Results and Discussions}

For all cases, the maximum response is observed due to the load case of the response spectrum function in (U1) direction with 0.05 eccentricity for all diaphragms. Since the building was symmetric, the results were obtained only in one direction ((U1), X-direction).

\subsection{Story Displacement}

Figure 14 shows the relationship between the story height and the maximum story displacement. It could be seen that, the maximum displacement value was recorded at the maximum height for all cases. Case (10), in which there were floating columns in every story, had the maximum displacement value by an increasing of about $75 \%$ compared to case (1), in contrast, case (11), which was the same as case (10) but with presence of shear walls, had the minimum displacement value by a decreasing of about $48.23 \%$ compared to case (1). Compared to case (1) and from case (2) to case (5), it could be seen that increasing the number of floating column above the $1^{\text {st }}$ floor, led to increasing of the lateral displacement by about $1.26 \%, 2.69 \%, 9.95 \%$, and $23.768 \%$ for case (2), case (3), case (4), and case (5), respectively. From case (5) to case (8), it could be noticed that, the higher was the location of the floating columns, the less lateral displacement was obtained. Compared to case (5), it was noticed that increasing the height of the location of the floating columns, led to increasing the maximum displacement by about $2.21 \%$ for case (6) and decreasing the maximum displacement by about $8.23 \%$ and $9.60 \%$ for case (7) and case (8), respectively. Case (9) showed an increasing difference in lateral displacement by about $2.46 \%$ compared to case (1).

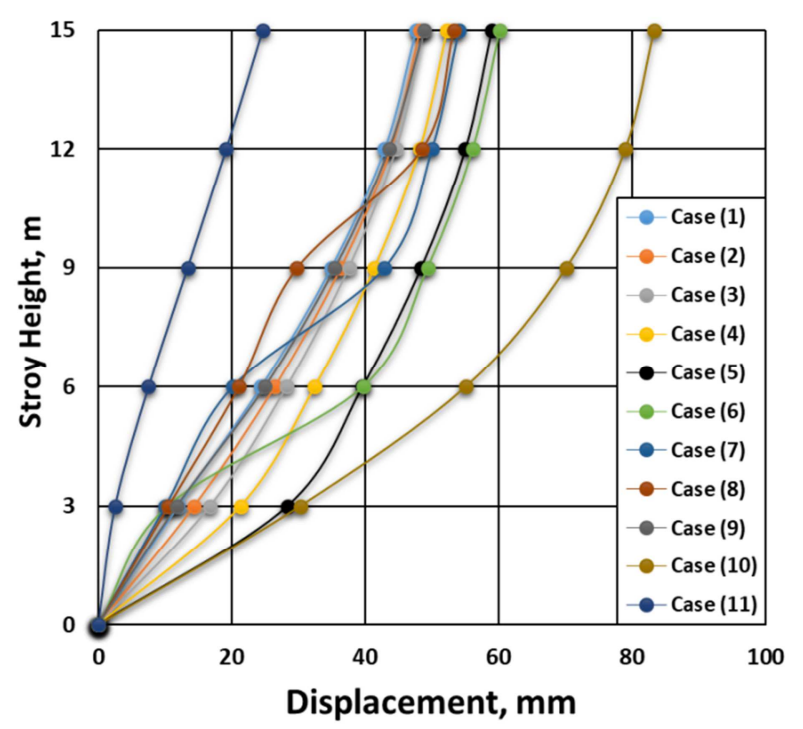

Figure 14. Maximum lateral story displacement with respect to story height.

\subsection{Story Drift}

Figure 15 shows the relationship between the maximum stories drift and the story height for all cases. It could be noticed that, for cases (2) to (5), maximum story drift was for the first story where the floating columns were introduced. Compared to case (1), increasing the number of floating columns, led to increasing the story drift by about $20 \%$, $42.4 \%, 96.48 \%$, and $140.41 \%$ for case (2), case (3), case (4), and case (5), respectively. For cases (5) to (8), it could be seen that the maximum story drift was located at the story over which the floating columns were introduced. Compared 
to case (5), it was noticed that increasing the height of the location of the floating columns, led to increasing the maximum drift by about $6.48 \%$ for case (6) and decreasing the maximum drift by about $12.07 \%$ and $21.63 \%$ for case $(7)$ and case (8), respectively. Case (10) recorded the maximum story drift at the first story by an increasing of about $157 \%$ compared to case (1), in contrast to case (11) which recorded the minimum story drift at the same location by a decreasing of about $79.12 \%$ compared to case (1). Case (9) compared to case (1) had an increasing difference in story drift by about $7.7 \%, 1.76 \%$, and $9.69 \%$ for the second story, the fourth story, and the fifth story, respectively. The other stories had also an increasing difference but less than $1 \%$.

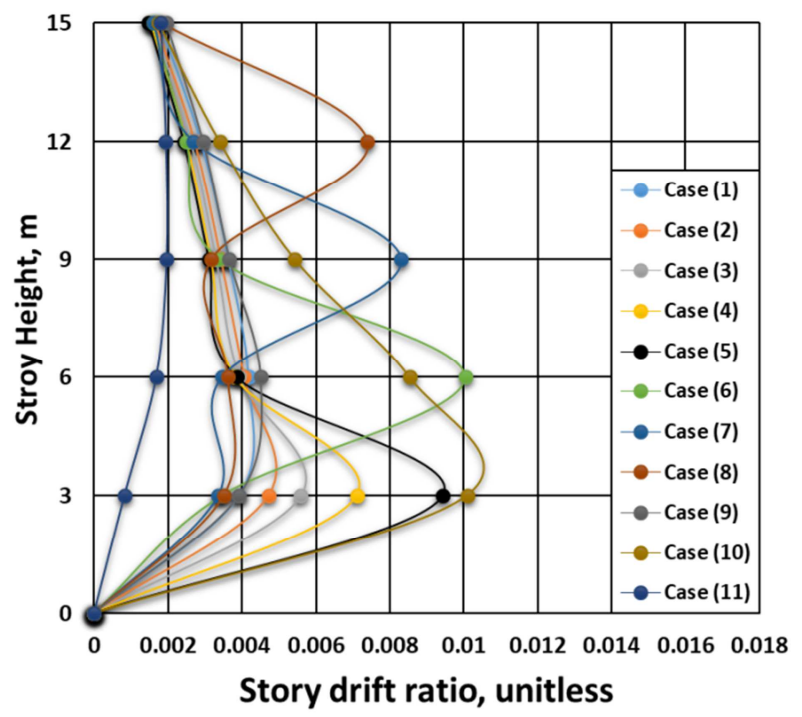

Figure 15. Maximum stories drift with respect to story height.

\subsection{Story Stiffness}

Figure 16 shows the variation of stories stiffness along the building height for all cases. For cases (2) to (5), it could be observed that, as the number of floating columns increased, the stiffness was decreased. Compared to case (1), increasing the number of floating columns, led to decreasing the story stiffness by about $21.06 \%, 36.67 \%$, $52.36 \%$, and $64.42 \%$ for case (2), case (3), case (4), and case (5), respectively. For cases (5) to (8), it could be seen that the minimum story stiffness was recorded at the story which the floating columns were introduced. Compared to case (5), it was noticed that increasing the height of the location of the floating columns, led to decreasing the story stiffness by about $14.97 \%, 15.53 \%$ and $16.05 \%$ for case (6), case (7) and case (8), respectively. Case (10) recorded the minimum story stiffness at the first story by a decreasing of about $66.57 \%$ compared to case (1), in contrast to case (11) which recorded the maximum story stiffness at the same location by an increasing of about $568.92 \%$ compared to case (1). Case (9) compared to case (1) had a decreasing difference in story stiffness by about $3.31 \%, 12.25 \%$, $6.22 \%, 5.712 \%$ and $10.68 \%$ for the first story, the second story, the third story, the fourth story, and the fifth story, respectively. In this study and according to ASCE7-16, there are no soft story cases.

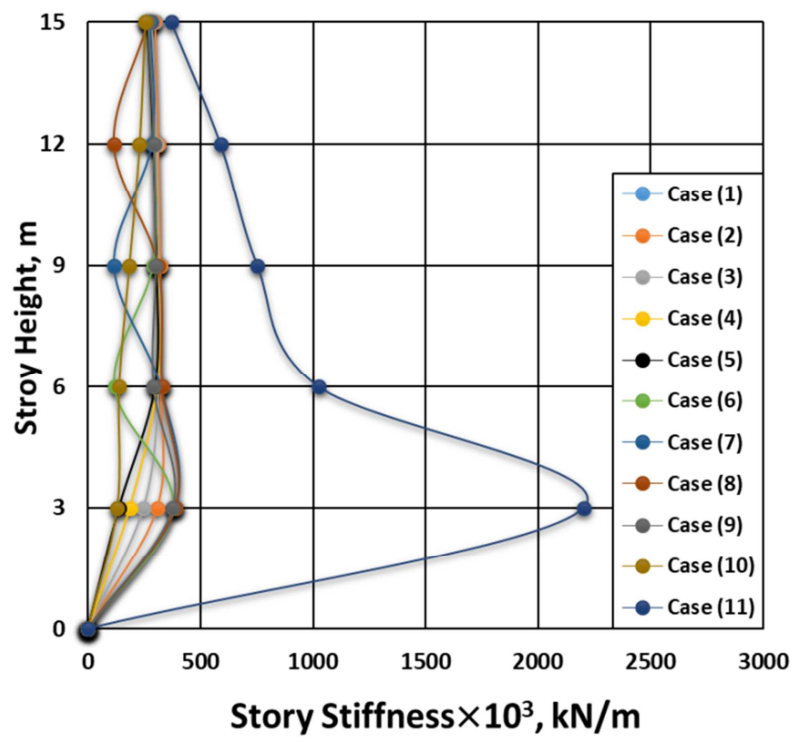

Figure 16. Variation of story stiffness with respect to story height.

\subsection{Response Spectrum Modal Period}

Figure 17 shows the variation of response spectrum modal period for all cases. Generally, From Figures 16 and 17 , it could be observed that the time period increased as the stiffness decreased. Also Figure 17 indicates that, at mode 12, (in which the modal participating mass ratios were over 90\% according to ASCE7-16 [10], and for cases (2) to (5), it could be observed that increasing the number of floating columns, led to increasing the time period by about $0.90 \%, 2.70 \%, 9.00 \%, 20.72 \%$ for case (2), case (3), case (4), and case (5), respectively, compared to case (1). For case (5) to case (8), the increasing was ranging from $3.73 \%$ to $5.22 \%$ for case (6) to case (8) compared to case (5). Case (10) had the maximum time period by an increasing of about $39.63 \%$ compared to case (1), in contrast, case (11) had the minimum time period by a decreasing of about $27.67 \%$ compared to case (1).

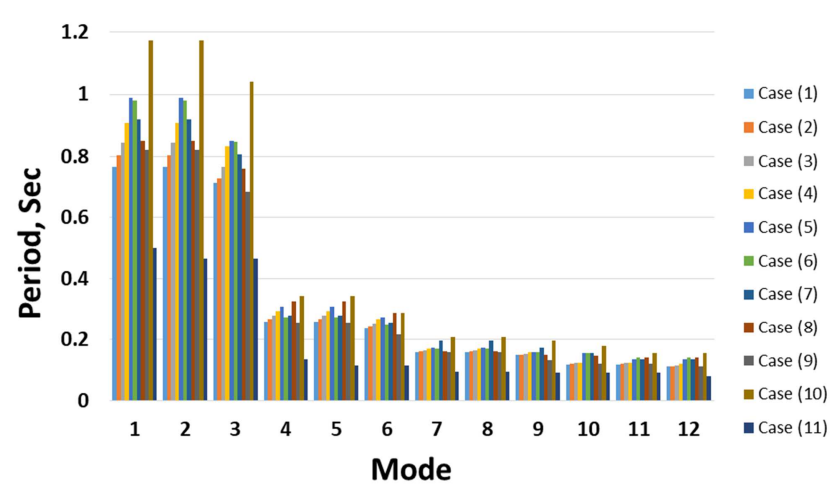

Figure 17. Variation of response spectrum modal period of all cases.

\section{Conclusions}

Based on the obtained analysis results, the following 
conclusions can be drawn:

1) The building with floating columns had an increasing displacement and drift than the building without floating columns. Also had a decreasing stiffness and hence, an increasing of the time period.

2 ) Increasing the number of floating column above the $1^{\text {st }}$ floor, for case (5) compared to case (1), led to increasing of the story displacement by about $23.76 \%$ and drift by about $140.41 \%$, also led to a decreasing of the story stiffness by about $64.42 \%$ and increasing of the time period by about $20.72 \%$.

3 ) Increasing the height of the location of the floating columns, for case (8) compared to case (1), led to decreasing of the lateral displacement by about $9.6 \%$, decreasing of the drift by about $21.63 \%$, decreasing of the story stiffness by about $16.05 \%$, and increasing the time period by about $5.22 \%$.

4) The building with floating column over cantilevers case (9) had not a significant response compared with building without floating columns case (1).

5) Case (10) had the maximum response between all cases because floating columns were introduced in all stories, to mitigate this response; shear wall-frame interactive system (case (11)) may be used.

\section{Recommendations for Future Work}

1) Study the effect of floating columns in different seismic zones.

2) The effect of using different of lateral resisting systems on a multistory frame RC building with floating columns.

3) Comparative study of a multistory frame RC building using different codes provisions.

\section{Declarations of Interest}

The authors declare that they have no competing interests.

\section{References}

[1] Thomas, J., George, N. (2015) Dynamic Analysis of Reinforced Concrete Building with Floating Column, International Journal of Engineering Research \& Technology (IJERT). NCRACE-2015 Conference Proceedings, Volume 3, Issue 29, pp. 1-6.
[2] Prasannan, P., Mathew, A. (2017) Seismic Performance of RC Floating Column Considering Different Configurations. International Journal of Engineering Research \& Technology (IJERT), Vol. 6 Issue 05, May - 2017, pp. 100-107.

[3] Chaudhari, A. N., Talikoti, R. S. (2017) Study of Seismic Behavior of Building with Different Positions and Types of Floating Column. International Journal of Engineering Science and Computing, July 2017, Volume 7 Issue No. 7, pp. 14056-14063.

[4] Gupta, T. S., Kumar, M. P. (2017) Effect of Floating Columns in R. C Frames at Different Seismic Zones in India. International Journal of Scientific Engineering and Technology Research, Volume. 06, Issue No. 11, March-2017, Pages: 2194-21964-7.

[5] Maitra, K., Serker, N. H. M. K. (2018) Evaluation of Seismic Performance of Floating Column Building. American Journal of Civil Engineering. Vol. 6, No. 2, 2018, pp. 55-59. doi: 10.11648/j.ajce.20180602.11. https://doi.org/10.11648/j.ajce.20180602.11.

[6] Rangwala, M. A., Singh, S. K. (2018) Seismic Analysis of Multi-Storey Frame with and Without Floating Columns. International Journal of Innovative Research in Science, Engineering and Technology, Vol. 7, Issue 5, May, pp. 52625272. https://doi.org/10.15680/IJIRSET.2018.0705096

[7] Patel, Trupanshu \& Gadhiya, Jasmin \& Bhatt, Aditya. (2017) Effect of floating column on RCC building with and without infill wall subjected seismic force. International Journal of Engineering Trends and Technology. 47. 206-212. 10.14445/22315381/IJETT-V47P233.

[8] Abdul Azeed, Beebijahira H Talageri, Nidith Kumar Shetty, Sankarshan M. (2019) Analysis And Design Of Residential Building With Floating Column. International Research Journal of Engineering and Technology. Vol 6, Issue 5, May.

[9] S, Gokul \& R, Manju. (2021) Study on Performance of Floating Column with Different Configurations. International Journal of Advanced Research in Science, Communication and Technology. 749-759. 10.48175/IJARSCT-1312.

[10] ASCE7-16 (2017) Minimum Design Loads and Associated Criteria for Buildings and Other Structures in Seismic Design Requirements for Building Structures: Structural Engineering Institute.

[11] ACI 318-14 (2014) Building Code Requirements for Reinforced Concrete and Commentary. 